\title{
Behavioural Survey of Local Inhabitants' Views and Attitudes about Slovak Karst National Park in Slovakia
}

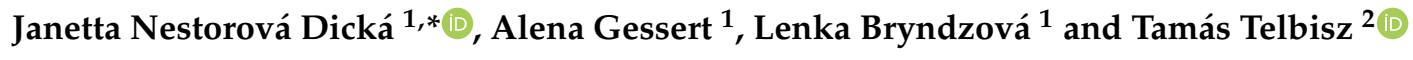 \\ 1 Institute of Geography, Faculty of Science, Pavol Josef Šafárik University, Jesenná 5, 04001 Košice, Slovakia; \\ alena.gessert@upjs.sk (A.G.); lenka.bryndzova@gmail.com (L.B.) \\ 2 Department of Physical Geography, Eötvös Loránd University, Pázmány Péter 1/C, 1117 Budapest, Hungary; \\ telbisztom@caesar.elte.hu \\ * Correspondence: janetta.nestorova-dicka@upjs.sk; Tel.: +421-55-234-2255
}

Received: 29 October 2020; Accepted: 27 November 2020; Published: 1 December 2020

\begin{abstract}
Park-people relationships are crucial for the effective operation of national parks (NPs). According to this new paradigm, protected areas are increasingly considered as instruments for regional development, particularly in marginal regions. However, park-people relationships often comprise conflicts. We tried to understand park-people relationships through the views and attitudes of local people living in or around the area of the Slovak Karst NP, which is found in a marginal, less developed region within Slovakia. We carried out a questionnaire survey and applied multidimensional statistical methods for the results. We identified four attitude dimensions and six local people clusters. Clusters were compared in terms of socio-demographic characteristics, views on $\mathrm{NP}$ tasks, attitudes towards the NP, tourism and nature, as well as migration intentions. We found that $45 \%$ of the sampled population had positive attitudes towards the NP and nature, $29.5 \%$ were neutral and $25.5 \%$ had somewhat negative feelings. Results showed that the personal economic situation, the relationship with tourism, age, education level and profession all influence the attitude of local people towards the NP. As for the socio-economic development of the region, we found that till now, the Slovak Karst NP had only a limited role. Nonetheless, understanding the views and attitudes of local people may help to refine the NP strategy. Results suggest that NP management should strengthen the interaction with local communities and improve resource efficiency through a participatory approach to preserve natural values, improve the quality of life and stop outward migration from the region.
\end{abstract}

Keywords: local people; national park; attitude; tourism; sustainability; cluster analysis; Slovak Karst

\section{Introduction}

Park-people relationships have been in the focus of researchers and managers alike for several decades as the interactions between local populations and protected areas play a crucial role in the successful management of national parks [1]. National parks (NPs) and, even more so, geoparks are often found in karst areas because of their special geomorphological values, such as caves, gorges or sinkholes [2-5]. On the other hand, karst terrains are frequently relatively sparsely populated and less developed areas [6-9]. In addition, areas situated along national borders also have some disadvantages from a social point of view. Nonetheless, these drawbacks (low population, lower level of economic development) can be favourable for the preservation of the natural environment, i.e., for the creation of protected areas; thus, a surprisingly high number of NPs are situated along national borders [9-13].

In general, the attitude of the local population towards protected areas is significantly influenced by the local context, i.e., by the historical, geographical, cultural and political conditions [14-17]. 
Recently, local communities have had an increasing role in NP management. Solid cooperation between park management and local inhabitants is a necessary prerequisite to achieve harmony between NP nature protection objectives and sustainable development [18-20]. Living in a karst area can provide both advantages and disadvantages to the local population. For example, benefits lie in the possibility of using the natural and cultural potential for the development of tourism. However, human presence alters the karst landscape, and proper stakeholder functioning requires an adequate management system [21]. Moreover, the elaboration of a long-term sustainable social-ecological system can positively contribute to the management of local cultural and natural resources and empower the local community [22]. Besides the preservation of nature, an important goal of management should be to support the survival of rural communities in karst NPs.

In this context, our first study question is whether an NP can influence the local socio-economic development, or more specifically, how much an NP can influence it. Strictly economic approaches (e.g., $[23,24])$ found that the direct economic impacts of protected areas are rather hard to prove. Nevertheless, the improving infrastructure, the favourable structural change and the benefits for the tourism industry contribute to regional sustainable development. In our study, we do not deal with direct economic indicators; instead, we examine what local people think about their personal or settlement-scale development. The second goal of our study is to explore the factors in the background of how local people consider their NP. Finally, the third general question is whether protected areas are a resource or a constraint for local people. Since park-people relationships are variable by country and by region, they can only be understood through case studies. In this paper, we investigate the Slovak Karst NP as a case example in order to expand our knowledge about park-people relationships.

The Slovak Karst NP is situated in the southeastern part of Slovakia. It is a perfect representative of the above properties as it is an NP located in a karst area and located next to the national border. The Slovak Karst NP is rich in natural resources and potential. However, its social and economic situation is fairly complex, and this fact significantly influences the possibility of sustainable development. A previous study including the Slovak Karst area stated that the general environmental awareness of the public (tourists and inhabitants alike) was very low, and the main hope for the development of the region lies in tourism, while experts believed that the potential conflicts between tourism and nature protection were small [25].

The main goal of our study is to examine the basic attitudes of the local population towards the Slovak Karst National Park and tourism development by employing a questionnaire survey. To explore basic attitude dimensions and to discriminate clusters of local people, who share the same attitudes, a multidimensional statistical analysis is applied. Clusters are compared in terms of socio-demographic characteristics, views on NP tasks, attitudes towards the NP, tourism and nature, as well as migration intentions. We believe that recognising the views and attitudes of the inhabitants can help to create stronger relationships between the NP and local stakeholders, especially in the area of tourism.

\section{Theoretical Background}

In the area of NPs, three main groups of interest exist, the NP, the local people and the tourists. Each group has its own interests, but they also share common goals as well. In this section, the complex relationships among these groups are briefly outlined, although it is not possible to cover the whole picture in such a brief section. In addition, some special features of karst NPs from the viewpoint of tourism are also mentioned.

\subsection{Park-People Relationships}

The exploration of the relationships between natural and socio-cultural settings requires interdisciplinary research [26-28]. The main goal of environmentalists, NP employees, scientists and a significant part of the population is to preserve the landscape in a near-natural state. Tourists desire to enjoy their stay in the area. Finally, local people want to improve their living conditions through economic development. As a result, the priorities of the NP, the tourists and the stakeholders differ on 
certain issues $[17,29,30]$. The correct identification of the needs and problems of all stakeholders is imperative to create a functional model of karst protected area management [31-34]. Thus, most authors point out that a prosperous state in an NP can be achieved only if we know the attitudes and views of all stakeholders [17].

Park-people relationships were reviewed by Zube and Busch (1990) [1]. They found that the most important issues in this context are: the participation of locals in the operation of the NPs, the services provided by the NPs to the local communities, the preservation of traditional land uses and, finally, tourism to the NP. Based on expert opinions from many countries on several continents, they found that tourism to the NP is the most generally important factor for local people among the abovementioned issues.

International initiatives at the highest levels, like the International Union for Conservation of Nature (IUCN) Global Protected Areas Programme (GPAP, 2017-2020), point out that no protected area system could be established or managed without the participation and involvement of people. In this way, they directly support local communities within the framework of sustainable regional development connected to nature-friendly forms of tourism $[28,35,36]$.

The observation of natural phenomena and aesthetically significant parts of the landscape is a basic goal of active tourism in karst areas. Sabolová (2013) [37] noted that tourism development in all its forms has an impact on the domestic population. Muganda et al. (2013) [38] added that the involvement of local communities is a key issue to the sustainability of the tourism industry. Many experts have also outlined the importance of the interaction between local communities and tourism development [39-44].

Caves are an important element of the natural potential of karst areas. The most important factors that rank the caves in desired tourist destinations are their aesthetics, their unique decoration and, in particular, the "adventure factor" [45]. Even though caves provide an excellent precondition for tourism development, a cave visit in itself is only a short-term form of tourism. Thus, the mere presence of a cave will not ensure satisfactory tourism development. It can be reached only if further factors including site accessibility, additional nearby tourist attractions and good tourist infrastructure are present [46]. Hochmuth (1997) [47] noted that the local economic situation can also be very important.

Within the last few decades, the management practices of NPs have considerably changed. NPs are now more dynamic and innovative; coordinating conservation and the sustainable utilization of nature is seen as advantageous for both conservation and regional development [28,48-50]. Eagles et al. (2002) [51] pointed out that, in line with the guidelines of the IUCN, the potential benefits of strengthening economic opportunities, protecting the natural and cultural heritage and improving the quality of life must be identified. Tourism development can generate financing for the management of protected areas and can help communities cope with economic restructuring [52].

The majority of current studies regarding the issue of local attitudes towards conservation and especially the development of NPs present the results of qualitative research describing selected case studies [53-63]. According to Pietrzyk-Kaszyńska et al. (2012) [63], although qualitative research makes a valuable contribution to the description of conflicts and the significance of various social actors, it does not provide representative information on local communities and does not allow for the evaluation of significant factors that influence inhabitants' attitudes. Schindler et al. (2011) [64] confirmed that quantitative research is also necessary to characterise local situations.

The protection of karst landscapes involves both physical and human geographical aspects [12,65-67]. The physico-geographical aspect includes the protection of biological, geological/ geomorphological and hydrological values. The human-geographical aspect comprises the preservation of cultural and historical values including both monuments and living traditions. In addition to protection, education, scientific research and tourism development are also among the tasks of NPs. The integration of human-geographical aspects and physico-geographical aspects through the implementation of sustainability principles is the aim of many NPs, for instance in Finland [68]. All of the above components influence the operation and development of NPs. Hence, NPs increasingly 
function as intermediaries between local and national interests in both nature conservation and regional development issues [69].

The integration of the human component into the operation of NPs is often neglected in the post-communist states of Central and Eastern Europe [62,70,71]. Most national parks in this part of Europe were created during the communist period. As Kőszegi et al. (2019) [72] stated, the Soviet Union supported the creation of an international network of protected areas for ideological reasons. In the Soviet-based economic system, landowners could not use their own land. Though many rural people became landowners after the change of the regime, the protected areas generally remained under state control. For decades, this has led to tensions in society and does not contribute to a good atmosphere between local people and the national park. Moreover, traditional agricultural activity was not competitive in karst areas, so people gradually looked for other livelihoods, and many of them migrated away from the territory. At present, as protected areas are discovered by domestic and foreign tourists, some people, who previously left the area, gradually return to the territory to join the local tourism industry [73]. Consequently, the views about the role of local people have changed, and their knowledge is now considered crucial in long-term sustainable development $[31,63,74]$.

\subsection{Presentation of the Hypotheses}

In the present empirical study, we investigate the NP-local people-tourism "triangle" from the viewpoint of local people and try to answer whether the abovementioned international trends are valid for the case of the Slovak Karst NP. Finally, based on the empirical results, we formulate some general advice, which can help to improve park-people relationships.

A wide range of attitudes towards NPs (or protected areas in general) were reported by different authors. For instance, in their analysis about Komodo NP (Indonesia), Walpole and Goodwin (2001) reported very high support for conservation (93.7\% considered the NP as a positive). In the study of Anthony (2007) about Kruger NP (South Africa), the author found that the mean attitude index towards the NP was 2.14 on a scale from -12 (strongly negative) to +12 (strongly positive). Futhermore, some European examples are also mentioned here. Cihar and Stankova (2006) found that the Podyji/Thaya River Basin NP (Czech Republic) was viewed positively by $62 \%$ of local residents in 2000, after nine years of the park's existence. In the same study, the authors stated that residents indicating negative feelings towards the influence of the Podyji NP in their daily lives were in a slight minority, while in the nearby Sumava NP, the residents with negative feelings were in a slight majority. Zawilińska (2020) studied Ojców National Park (Poland) and experienced that more than half of the respondents (57.4\%) only named positive things about the NP, whereas those with solely negative connotations were also relatively numerous (22.5\%). Finally, some others came up with both positive and negative connotations ( $8.3 \%$ ) or neutral connotations only ( $2 \%)$. Based on the above studies related to Central European countries, we formulated our first hypothesis H1 as follows:

Hypothesis 1 (H1). The majority of the local people have positive attitudes towards the Slovak Karst NP, but significant groups of neutral or negative views also exist.

It is also important to discover the factors that may influence local people's attitudes in a positive or negative direction. Anthony (2007) cited several papers that demonstrated that increased household wealth positively influenced attitudes towards NPs; however, according to his results about Kruger NP, household income per se had no significant influence on attitudes towards the Park. He also added that more positive attitudes were mainly influenced by age and by having a household member employed by the NP. Many of the neutral responses were from those who had never talked with NP staff or were unaware of any NP activities or benefits. On the other hand, negative attitudes were primarily related to people involved in animal husbandry. Fialo and Jacobson (1995) conducted a survey in Machalilla NP (Ecuador). Their results showed that both age and education levels significantly affected attitudes. People under 40 years old were more likely than their elders to support the Park, and respondents 
with no education held more negative attitudes towards the Park than respondents with schooling. The results of Tomićević et al. (2010) indicated that the attitudes of local people towards conservation in Tara NP (Serbia) were mainly influenced by education (education has a significant influence on having a positive attitude towards conservation), the age of respondents (younger people have more positive attitudes towards conservation than older people) and whether they have worked for the NP or not (respondents who work for the NP tend to have a good relationship with the NP and a positive attitude towards conservation). The reasons for rural marginalisation and outmigration in Slovakia were studied by Ira and Huba (1999), who pointed out that the improvement of public participation in nature conservation can help stabilise the rural population and decrease outmigration. Taking into consideration the above results, our second hypothesis $\mathrm{H} 2$ is the following:

Hypothesis 2 (H2). More positive attitudes towards the Slovak Karst NP are typical of people with a higher level of education, younger age, who more involved in tourism and who have a preference not to migrate away from the area.

Walpole and Goodwin (2001) stated in their aforementioned study about Komodo NP that the vast majority of local people supported tourism development $(92.7 \%$ would be happy to see more tourists). Muresan et al. (2016) studied the whole region of Nord-Vest Romania, where 170 protected areas (including two national parks and two natural parks) are found. Their results demonstrated that rural residents perceive tourism development positively. Futhermore, they found that rural residents see tourism as an income generator, but at the same time, they understand the importance of planning and managing tourism destinations sustainably. However, they added that the local community was willing to support sustainable tourism development if the personal benefits perceived were important. In the study of Brankov et al. (2015) about Djerdap NP (Serbia), fifty-five percent of locals agreed that tourism had a direct impact on the improvement of infrastructure, and the vast majority (91\%) supported the development of sustainable tourism. Most people recognized tourism as a possible driver of development and had a positive attitude towards this activity, although only a part of the respondents indicated a personal benefit from tourism (38.3\%). Based on the above results, our third hypothesis $\mathrm{H} 3$ is the following:

Hypothesis 3 (H3). Tourism is considered by most people in Slovak Karst NP as the main potential driver for sustainable development.

\section{Location, Values and Tourism of the Slovak Karst NP}

The Slovak Karst is one of the largest continuous karst terrains in Slovakia and Central Europe. It is situated in the southern part of Eastern Slovakia, and the karst area extends into Hungary as well, where it is called Aggtelek Karst. Altogether, they form the Gömör-Torna Karst System. The NP's eastern border is approximately $40 \mathrm{~km}$ from the second largest city of Slovakia, Košice, and the Slovak Karst is around $300 \mathrm{~km}$ from Bratislava, the capital. The lack of a connected highway network has a significant negative impact on the tourist traffic of the NP. The Slovak Karst area is exceptional in its geological and landscape character; thus, it enjoys protection at several national and international levels. It is an NP and a UNESCO Man and Biosphere Reserve, and its caves are inscribed on the UNESCO Natural World Heritage List.

The Slovak Karst area has a complex geological structure. It comprises the Silicicum, Gemericum, Bôrka Nappe, Meliaticum and Turnaicum tectonic units, which build up its nappe structure. Mesozoic carbonate rocks are the most typical for the $800 \mathrm{~km}^{2}$ area of the Slovak Karst. Its geomorphology is dominated by eight karst plateaus (Jasovská Plateau, Zádielská Plateau, Horný vrch, Borčianska Plateau, Dolný vrch, Silická Plateau, Plešivecká Plateau and Koniar), which are at elevations between 550 and $800 \mathrm{~m}$ asl. The limestone plateaus were created as planation surfaces mostly during the Tertiary, and they are rich in well-developed surface and underground karst forms including dolines, karren, 
dry valleys, uvalas and caves. The plateaus are divided by $300-400 \mathrm{~m}$ deep gorges. The gorges have a classical fluviokarstic genesis with caves situated in the hillsides indicating a complex valley evolution during the Quaternary.

With an area of $346 \mathrm{~km}^{2}$ and a buffer zone of $117 \mathrm{~km}^{2}$, the Slovak Karst was declared an NP in 2002 because of its natural, aesthetic and cultural values (Figure 1). Nonetheless, it was the last step in a series of protection measures: the "Slovak Karst Protected Landscape Area" was declared in 1973; it was the first Slovak area registered in the "international network of biosphere reserves under UNESCO Man and the Biosphere" in 1977; the Caves of Aggtelek and Slovak Karst were inscribed on the UNESCO World Heritage List in 1995; and Domica Cave was added to the "List of Wetlands of International Importance of the Ramsar Convention" in 2001. This last title was given because Domica Cave is a unique European example of natural underground wetlands, and its underground karst waters have great hydrological significance. In addition to its main area, the current NP also includes 10 national nature reserves, 6 nature reserves, and 16 national natural cave monuments.

From a tourist point of view, the reasons for visiting Slovak Karst NP are the varied geomorphological and geological features, as well as the fauna and flora, which are exceptional at both the national and international level. The presence of caves, gorges and waterfalls arouses the interest of domestic and foreign visitors alike [47]. However, as was demonstrated by visitor statistics, the Slovak Karst NP caves are among the least visited caves in Slovakia despite their spectacular aesthetic and scientific value and their inscription on the UNESCO World Heritage List [75]. This is at least partly due to the fact that the Slovak Karst area is located in a less developed region, far from the most popular tourist targets of Slovakia.

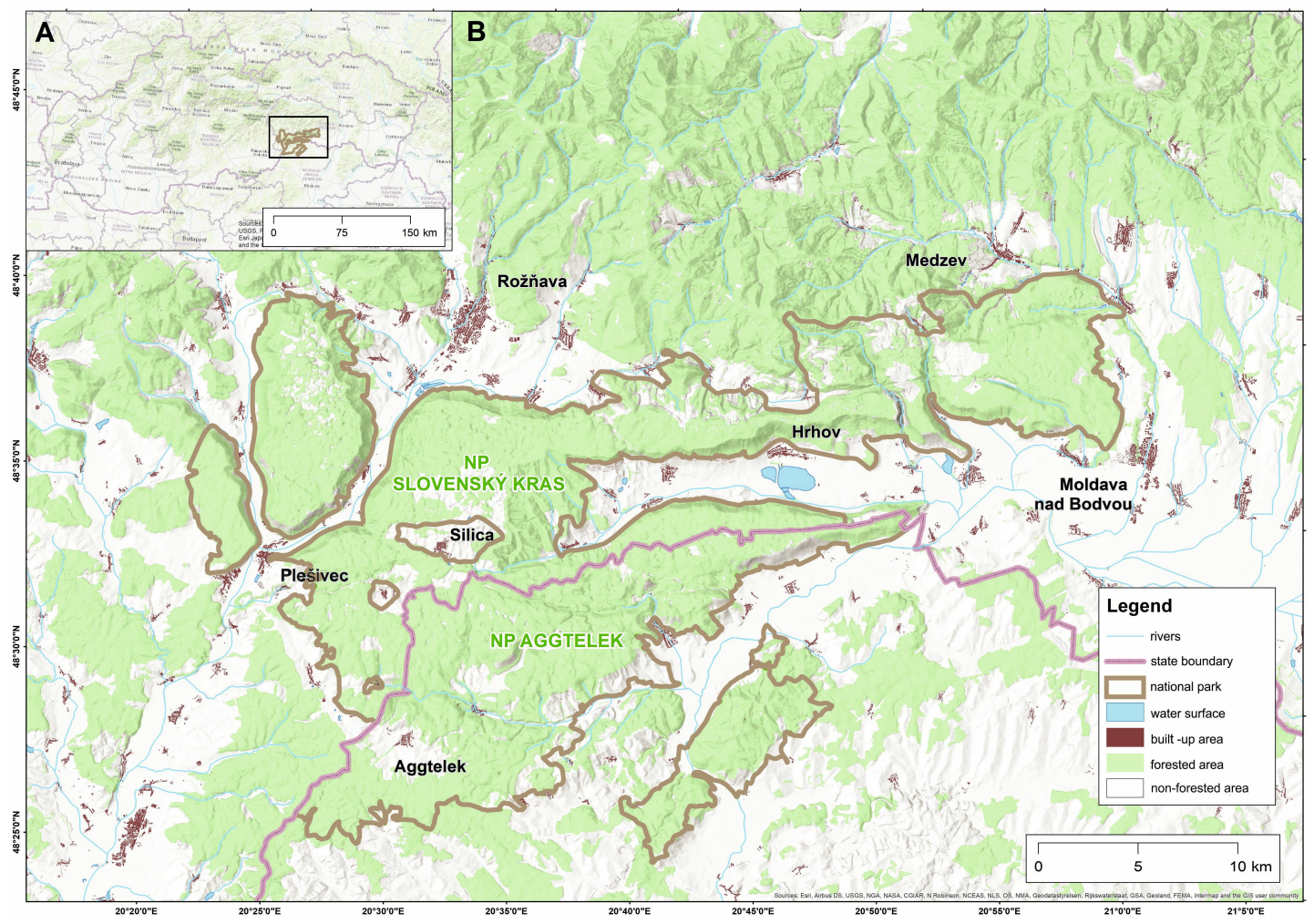

Figure 1. Location of Slovak Karst National Park (NP) (NP Slovenský kras) and its position in Slovakia. (A) Location of the Slovak Karst National Park within Slovakia, (B) The Slovak Karst National Park boundary. 


\section{Methodology}

\subsection{Data Collection}

The NP and the buffer zone area cover 40 municipalities with 35,000 inhabitants. We carried out a behavioural survey of population attitudes towards the Slovak Karst NP in these municipalities. We collected a "convenience sample" of local people. The onsite survey was realized from April to July 2019 by undergraduate students from the Geography Institute, Faculty of Science of the P. J. Šafárik University in Košice, Slovakia. Interviewers were informed of the study purpose, the survey subjects and the overall research methods. The questionnaires were administered using a direct face-to-face survey method because of the relatively high response rate of this method [76]. Respondents were representative in terms of gender and age. Their selection was a two-stage process. In the first stage, random sampling was conducted (simple sampling of by age and gender), and in the second stage, the pollsters chose respondents based on the quota. Quota was defined on the basis of data concerning the gender and age distributions of inhabitants living in the discussed municipalities.

Altogether, one-hundred sixty-eight questionnaires were filled, but nineteen of them proved to be unreliable because of several missing values; thus, the responses from 149 questionnaires were used for the data analyses. The processed responses represent $0.6 \%$ of the current adult population of the Slovak Karst NP area. Here, we note that the actual sample size is small; therefore, it is not enough to estimate statistically reliable proportions, so our study should be considered as exploratory. The limitations due to the small sample size are considered in the Discussion Section.

The questionnaire was developed as part of an international research project supported by the National Research, Development and Innovation Office of Hungary (NKFI). The title of the project is: "The changing role of karst NPs in human-environment relations: a regional comparison", and the aim is to understand the relationships between local people and karstic national parks in five East-Central European former communist states through case studies. The questionnaire was designed to be used (with small changes) in each case study and to gain comparable data from different countries and NPs. The questionnaire has 34 questions: 8 on socio-demographic characteristics, 7 related to the economic situation, 5 on attitudes towards the landscape, 4 on tourism, 9 on the relationship of local people with the NP and 1 on NP tasks.

\subsection{Data Analysis Techniques}

Figure 2 highlights the conceptual framework of the study. First, attitude factors were generated by factor analysis, and clusters of local people were created by cluster analysis. Second, we characterized the clusters by using the factor loadings of different attitudes in each cluster. Finally, we compared the clusters by one-way analysis of variance (ANOVA) and Chi-squared tests. As a result, we gained a complex image of local behavioural characteristics, which can be used for the refinement of future NP development strategies.

As for the technical details of the statistical analysis, varimax rotation was used in the factor analysis, and responses to 12 survey questions were used to determine the attitude factors. The analysis was based on the polychoric correlation recommended by many authors when the database comprises categorical data [77-79], and it was processed in the freely available 10.10.03 Factor program version devised by Ferrando and Lorenzo-Seva (2017) [80].

We extracted only factors with eigenvalues greater than 1.0 for this study, and K-means cluster analysis was used with the "grand-means for each dimension" as the input. The resultant algorithm was used to group respondents into mutually exclusive cluster groups using the nearest centroid sorting $[45,81]$. The number of cluster groups was subjectively established upon suitable available interpretation and the response number in each cluster. Finally, the Chi-squared and one-way ANOVA tests identified cluster differences in attitude factor loadings, and the Chi-squared results also highlighted the socio-demographic variation among clusters. 


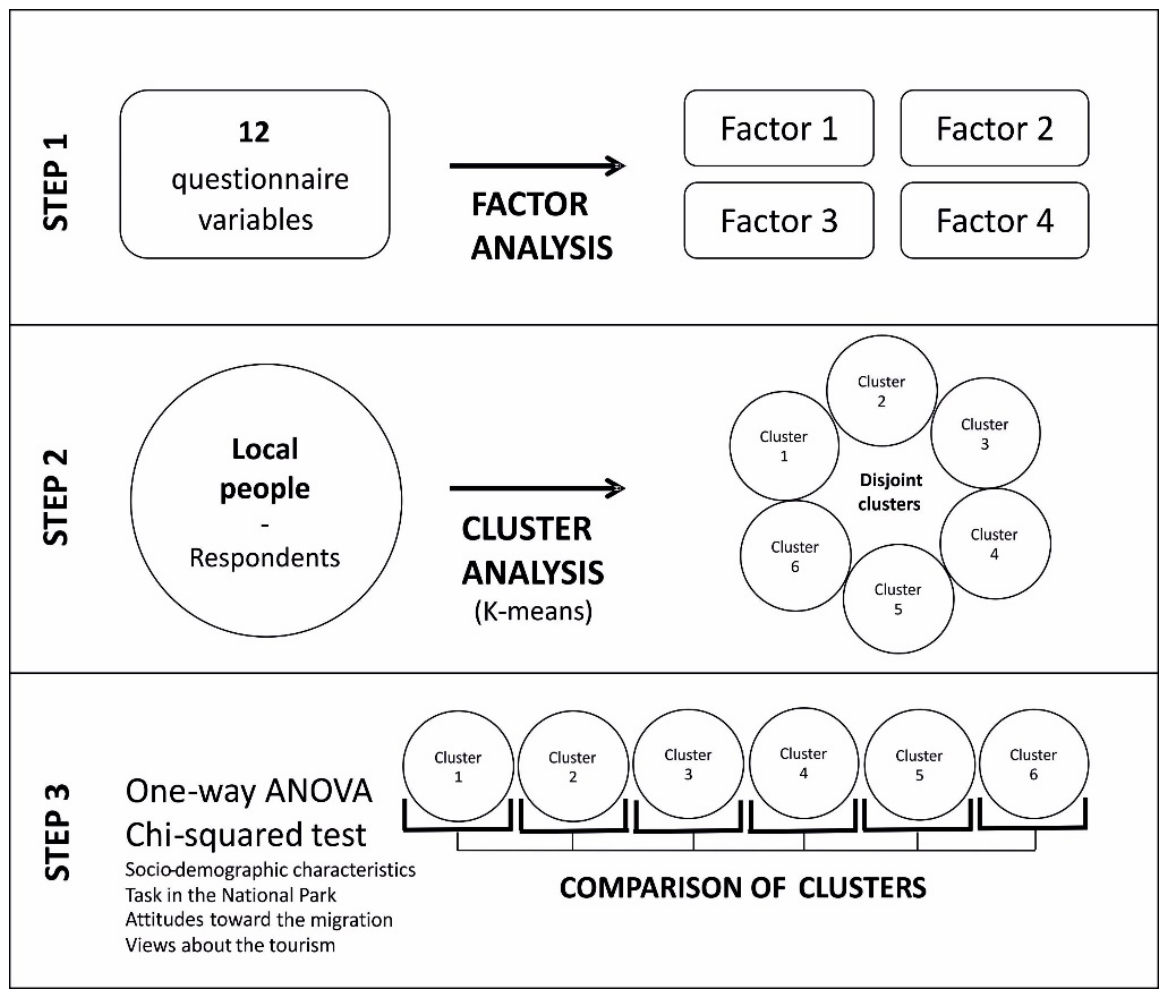

Figure 2. Statistical methodology framework of this study. Source: authors' elaboration.

\section{Results}

\subsection{Socio-Demographic Profile and Respondent Residence}

The study involved people over the age of 18 . Table 1 summarises the demographic profile of the respondents. In fact, fifty-three-point-seven percent were female; 40.3\% were aged 30-49, i.e., the economically most active population; $73.2 \%$ had a secondary school education, and $20.1 \%$ had a university diploma; $63.1 \%$ were employed, $12.1 \%$ unemployed and $24.8 \%$ another status, such as student, retired or on maternity leave. The proportions of the surveyed local inhabitants approximately corresponded to the gender and age composition of the population living in the territory of the Slovak Karst NP. In the settlements belonging to the Slovak Karst NP, there is a slight predominance of the female population (50.4\%) over the male population (49.7\%), similar to the population of Slovakia (Statistical office of Slovakia Republic, 2019). However, in our sample, there were slightly more females than males. Age categories 18-30, 30-50, 50-65, and more than 65 were represented in the sample approximately by the same proportions as in the total adult population of the study area. Twenty-one-point-three percent of the total population are aged $18-30 ; 37.2 \%$ are aged $30-50 ; 23.5 \%$ are aged 50-64; and 18\% are aged more than 65 years. As for education, the sample was biased towards higher levels, i.e., people having secondary education had a significantly higher proportion in the sample $(73 \%)$ than in the region (56\%), and the same was true for people with a university degree $(20.1 \%$ versus $15 \%$ ). However, it is noted that similar distortions (towards the more educated categories) are generally experienced in surveys.

Figure 3 shows the spatial distribution of the local respondents who took part in the survey. They were from 30 municipalities in and around the Slovak Karst territory. Over half of the respondents resided in the relatively larger Plešivec, Hrhov, Turňa nad Bodvou, Drienovec and Jablonov nad Turňou settlements with more than 800 inhabitants. Half the respondents were selected from smaller municipalities evenly distributed throughout the study site, and this combination ensured relevance and a representative population in each category from the size structure of the studied settlements. 
Table 1. Demographic characteristics of respondents $(\mathrm{N}=149)$.

\begin{tabular}{ccc}
\hline Variables & Category & $\%$ \\
\hline \multirow{2}{*}{ Sex } & Men & 46.3 \\
\cline { 2 - 3 } & Women & 53.7 \\
\cline { 2 - 3 } Age & $18-29$ & 19.5 \\
\cline { 2 - 3 } & 30-49 & 40.3 \\
\cline { 2 - 3 } & $50-64$ & 24.8 \\
\hline \multirow{3}{*}{ Education level } & 65+ & 15.4 \\
\cline { 2 - 3 } & Elementary & 6.7 \\
\cline { 2 - 3 } & Secondary & 73.2 \\
\hline \multirow{2}{*}{ Occupation } & University & 20.1 \\
\cline { 2 - 3 } & Unemployment & 12.1 \\
\cline { 2 - 3 } & Employment & 63.1 \\
\cline { 2 - 3 } & Other & 24.8 \\
\hline
\end{tabular}

Source: author's calculations.

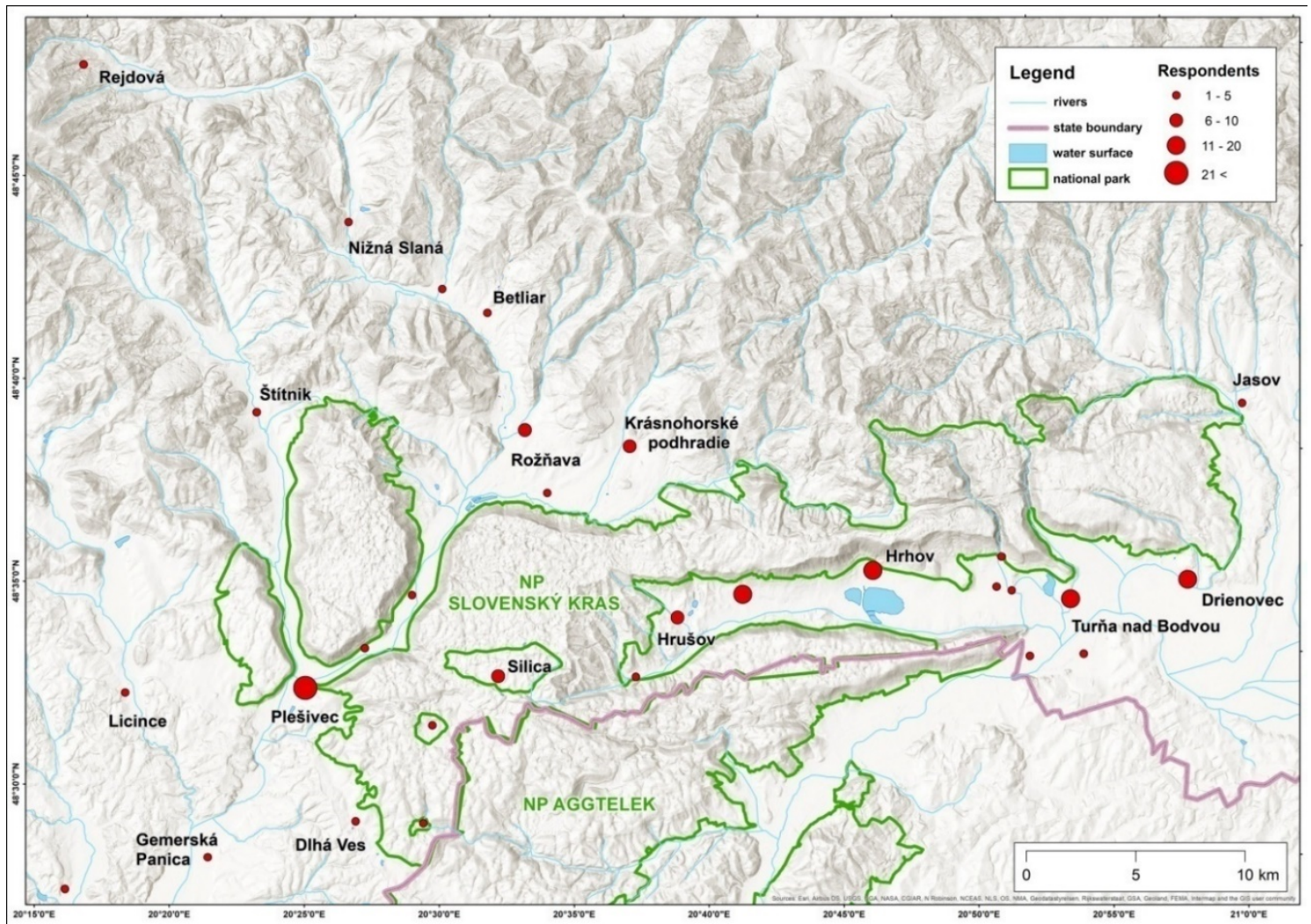

Figure 3. Respondents by residence. Source: authors' elaboration.

Information was also gained on whether respondents were born in the area and if they lived there permanently. The survey results demonstrated that $70.5 \%$ of respondents were born there and spent either their childhood or the last 18 years in the Slovak Karst. The remainder mostly mentioned marriages, relatives and housing as the motivating factors to reside in the area. 


\subsection{Attitude Factors for Local People}

Principal component factor analysis with varimax rotation identified an appropriate four-factor solution that provided factor eigenvalues greater than 1.0. The Kaiser-Mayer-Olkin measure of sampling adequacy produced a value of 0.77 indicating that this factor structure is an appropriate solution. Table 2 presents the analytical results and depicts that these factors accounted for $64.6 \%$ of the total variance.

Table 2. Analysis of local people's attitude factors.

\begin{tabular}{lcc}
\hline \multicolumn{1}{c}{ Attitude Dimensions (Factors) and Items (Survey Questions) } & $\begin{array}{c}\text { Factor } \\
\text { Loadings }\end{array}$ & $\begin{array}{c}\text { Variance } \\
\text { (\%) }\end{array}$ \\
\hline $\begin{array}{l}\text { Dimension 1 (General opinion about NP and tourism development) } \\
\text { "Is it important for you, that the NP is part of our national heritage and we can be proud of it?" }\end{array}$ & 0.80 \\
"Have you experienced any change due to easy border crossing without a passport (since 2007)?" & 0.71 & 22.70 \\
"In total, is the NP an advantage or a drawback for the settlement?" & 0.68 \\
"Would it be good if more tourists arrived at the settlement?" & 0.61 \\
Dimension 2 (Direct relationship with nature) & 0.82 \\
"How often do you visit local caves?" & 0.72 \\
"How often do you go into the 'nature' (surrounding forests, meadows)?" & 18.00 \\
Dimension 3 (Economic conditions) & 0.89 \\
"How has the economic situation changed during the last 10 years?" & 0.81 \\
"How do you see your personal (family) economic situation" & 0.67 \\
"How do you see the economic situation of your settlement" & 13.10 \\
Dimension 4 (Involvement in tourism and attitude to karst and nature protection) & 0.98 \\
"Do you have any personal relation to tourism?" & 0.70 \\
"Is it a blessing or a curse to live on a karst terrain?" & 0.50 \\
\hline
\end{tabular}

Source: author's calculations.

Items that correlated with the dimensions enabled us to nominate four generated factors; "General opinion about NP and tourism development" (Dimension 1), "Direct relationship with nature" (Dimension 2), "Economic conditions" (Dimension 3), and "Involvement in tourism and attitude to karst and nature protection" (Dimension 4).

The first dimension reveals connections between opinions on the NP and regional tourism development. The Slovak Karst NP is perceived as an advantage by almost $90 \%$ of respondents. The attitude of most local people is directed towards the necessity to increase tourism levels $(96.6 \%)$ and to improve current economic conditions and, ultimately, their own financial situation. Our results demonstrate the importance of the NP for municipalities and their inhabitants. The second dimension denotes the visiting rate of local people to the caves or nature in general and therefore expresses the direct relationship of people with natural values. The third dimension collects economic indicators from the household to settlement scale. The Slovak Karst region is one of the under-developed and poor areas in Slovakia with a predominantly rural character and low human capital [82-84]. Half the respondents stated that there has been a negative economic change in the last ten years, and this supports the need to improve the current economic level. The fourth dimension is the most mixed one. It includes the following parameters: local people's personal relationship with tourism through accommodation, catering or trade, their general attitude towards living in a karst area and their knowledge about the nature protection level of the area. The fact that knowledge about nature protection and tourism belongs to the same dimension suggests that people working in the tourism industry are more informed about nature protection and are aware that tourism in the area would be significantly less developed without the natural attractions of the NP.

\subsection{Clusters of Local Respondents}

Based on the cluster analysis, we identified six clusters (Table 3). Some features characteristic to several clusters are the following. Clusters 1 and 2 comprise local people who perceive the NP and the karst values rather positively and are open to tourism development. On the contrary, Clusters 4 and 6 consider 
all of these things more negatively. Cluster 2 contains people who are personally involved in tourism development through business and who have positive attitudes towards the NP and nature protection.

Table 3. Differences in the attitude factors by local people clusters.

\begin{tabular}{|c|c|c|c|c|}
\hline Clusters/Factors & $\begin{array}{l}\text { Factor } 1 \text { (General } \\
\text { Opinion about } \\
\text { NP and Tourism) }\end{array}$ & $\begin{array}{l}\text { Factor } 2 \text { (Direct } \\
\text { Relationship } \\
\text { with Nature) }\end{array}$ & $\begin{array}{c}\text { Factor } 3 \\
\text { (Economic } \\
\text { Conditions) }\end{array}$ & $\begin{array}{c}\text { Factor } 4 \text { (Involvement } \\
\text { in Tourism and } \\
\text { Attitude toward Karst } \\
\text { and Nature Protection) }\end{array}$ \\
\hline $\begin{array}{l}\text { Cluster } 1 \mathrm{~N}=35 \\
\text { (positive attitude toward NP and } \\
\text { tourism; unsatisfactory } \\
\text { economic conditions) }\end{array}$ & 0.79 & -0.30 & -0.83 & -0.21 \\
\hline $\begin{array}{l}\text { Cluster } 2 \mathrm{~N}=12 \\
\text { (very positive attitude toward } \\
\text { tourism, karst and nature protection) }\end{array}$ & 0.06 & -0.17 & 0.21 & 2.80 \\
\hline $\begin{array}{l}\text { Cluster } 3 \mathrm{~N}=20 \\
\text { (unsatisfactory economic conditions, } \\
\text { but significant relationship } \\
\text { with nature) }\end{array}$ & -0.55 & 1.15 & -0.96 & -0.02 \\
\hline $\begin{array}{l}\text { Cluster } 4 \mathrm{~N}=17 \\
\text { (negative attitude toward } \mathrm{NP} \text { and } \\
\text { tourism and insignificant relationship } \\
\text { with nature) }\end{array}$ & -1.83 & -0.77 & -0.16 & -0.40 \\
\hline $\begin{array}{l}\text { Cluster } 5 \mathrm{~N}=44 \\
\text { (good economic conditions) }\end{array}$ & 0.22 & 0.55 & 0.70 & -0.22 \\
\hline $\begin{array}{l}\text { Cluster } 6 \mathrm{~N}=21 \\
\text { (insignificant relationship with nature, } \\
\text { but good economic conditions) }\end{array}$ & 0.18 & -1.03 & 0.85 & -0.45 \\
\hline One way-ANOVA F-value & 84.229 & 59.912 & 68.092 & 138.051 \\
\hline$p$-value & 0.000 & 0.000 & 0.000 & 0.000 \\
\hline
\end{tabular}

Source: author's calculations.

One-way ANOVA confirmed that there are statistically significant differences between the clusters. In addition, the results show that Factor 1 "general opinion" and Factor 4 "tourism involvement and attitude" are the most influential factors in the discrimination of the attitude clusters. In contrast, Factor 2 shows only small differences between the clusters.

\subsection{Cluster Differences in Local People's Attitude toward NP Tasks}

The questionnaire survey included a set of questions focussing on NP tasks because we wished to recognize local opinion about the order of importance of NP tasks. The questions began with "According to you, how important should the following tasks be in the NP ...". The task list was compiled on generally accepted NP legal obligations and IUCN recommendations, and respondents had to evaluate the importance of these tasks on a 1-5 Likert-scale. The list included the following items: preservation of the biological values, preservation of the geological values (caves), preservation of the cultural values (monuments), preservation of the landscape, scientific research, education and tourism.

Again, we employed one-way ANOVA tests to decide if statistically significant differences existed between the opinions of people belonging to different clusters. Table 4 indicates that most people in all clusters gave relatively high scores for most of the listed NP tasks. Significant differences were identified only in three items at the $p=0.001$ significance level. The test revealed that people of different clusters have differing opinions about the importance of biological and geological preservation and tourism. People in Cluster 6, who rarely visit nature, but have satisfactory economic conditions, assessed biological and geological preservation as less important, while those in all other clusters considered these NP tasks very important. People in Cluster 4, who have a negative attitude towards the NP and tourism development, attributed the lowest importance to the tourism tasks of the NP. On the contrary, people in Cluster 2, who are involved in tourism and have a positive attitude towards living in this karst area, assessed the tourism tasks of the NP as the most important. 
Naturally, the economic situation of the Slovak Karst area significantly influences the local attitudes towards emigration. The highest level of emigration intent is connected to Cluster 3, because of the unsatisfactory economic conditions of these people and despite their close relationship with nature. On the other hand, people of Cluster 5, who enjoy good economic conditions, had the highest proportion of people preferring to remain in the region.

The perception of tourism is also varied. Approximately two-fifths of the local inhabitants experienced that there are many tourists in their settlements, while a variable $0-24 \%$ stated that they had never encountered tourists in their settlement. People in Cluster 2 with their very positive attitude toward tourism, karst and nature protection and people in Cluster 6 with a good economic situation, but insignificant relationship with nature experienced higher tourist influx. In contrast, the least number of tourists were reported by Cluster 5 respondents, who have good economic conditions, and especially by Cluster 4 people, who have negative attitudes towards both NP and tourism and have a weak relationship with nature.

\subsection{Cluster Differences by Local People's Socio-Demographic Characteristics}

Chi-squared tests identified the distinctive socio-demographic characteristics of the clusters and determined the statistically significant differences between clusters in the selected socio-demographic variables. Table 6 highlights that there are significant $(p<0.05)$ differences between the clusters in almost all socio-demographic variables. These include age, educational level and occupation, and the only variable without significant differences was gender, as the distribution of men and women was mostly equal in all clusters.

Table 6. Socio-demographic characteristics by clusters.

\begin{tabular}{|c|c|c|c|c|c|c|c|c|c|}
\hline \multirow{2}{*}{$\begin{array}{c}\text { Socio-Demographic } \\
\text { Characteristics }\end{array}$} & \multirow{2}{*}{$\begin{array}{l}\text { Cluster } 1 \\
\mathrm{~N}=35\end{array}$} & \multirow{2}{*}{$\begin{array}{c}\text { Cluster } 2 \\
N=12\end{array}$} & \multirow{2}{*}{$\begin{array}{c}\text { Cluster } 3 \\
N=20\end{array}$} & \multirow{2}{*}{$\begin{array}{c}\text { Cluster } 4 \\
\mathrm{~N}=17\end{array}$} & \multirow{2}{*}{$\begin{array}{c}\text { Cluster } 5 \\
\mathrm{~N}=44\end{array}$} & \multirow{2}{*}{$\begin{array}{c}\text { Cluster } 6 \\
N=21\end{array}$} & \multicolumn{3}{|c|}{ Pearson Chi-Squared } \\
\hline & & & & & & & Value & df & $p$-Value \\
\hline \multicolumn{10}{|l|}{ Sex } \\
\hline Men $(\mathrm{N}=69)$ & $48.6 \%$ & $41.7 \%$ & $50.0 \%$ & $58.8 \%$ & $43.2 \%$ & $38.1 \%$ & \multirow[b]{2}{*}{4.199} & \multirow{2}{*}{5} & \multirow[b]{2}{*}{0.521} \\
\hline Women $(\mathrm{N}=80)$ & $51.4 \%$ & $58.3 \%$ & $50.0 \%$ & $41.2 \%$ & $56.8 \%$ & $61.9 \%$ & & & \\
\hline \multicolumn{10}{|l|}{ Age } \\
\hline $18-29(\mathrm{~N}=29)$ & $17.1 \%$ & $16.7 \%$ & $35.0 \%$ & $23.5 \%$ & $11.4 \%$ & $23.8 \%$ & \multirow{4}{*}{29.026} & \multirow{4}{*}{15} & \multirow{4}{*}{0.016} \\
\hline $30-49(\mathrm{~N}=60)$ & $40.0 \%$ & $58.3 \%$ & $35.0 \%$ & $29.4 \%$ & $43.2 \%$ & $38.1 \%$ & & & \\
\hline $50-64(\mathrm{~N}=37)$ & $20.0 \%$ & $25.0 \%$ & $25.0 \%$ & $17.6 \%$ & $31.8 \%$ & $23.8 \%$ & & & \\
\hline $65+(N=23)$ & $22.9 \%$ & $0.0 \%$ & $5.0 \%$ & $29.4 \%$ & $13.6 \%$ & $14.3 \%$ & & & \\
\hline \multicolumn{10}{|l|}{ Education level } \\
\hline elementary $(\mathrm{N}=10)$ & $5.7 \%$ & $0.0 \%$ & $0.0 \%$ & $23.5 \%$ & $9.1 \%$ & $0.0 \%$ & \multirow{3}{*}{25.91} & \multirow{3}{*}{10} & \multirow{3}{*}{0.004} \\
\hline secondary $(\mathrm{N}=109)$ & $74.3 \%$ & $75.0 \%$ & $85.0 \%$ & $58.8 \%$ & $68.2 \%$ & $81.0 \%$ & & & \\
\hline university $(\mathrm{N}=30)$ & $20.0 \%$ & $25.0 \%$ & $15.0 \%$ & $17.6 \%$ & $22.7 \%$ & $19.0 \%$ & & & \\
\hline \multicolumn{10}{|l|}{ Employment } \\
\hline unemployment $(\mathrm{N}=18)$ & $17.1 \%$ & $0.0 \%$ & $20.0 \%$ & $17.6 \%$ & $4.5 \%$ & $14.3 \%$ & \multirow{3}{*}{20.737} & \multirow{3}{*}{10} & \multirow{3}{*}{0.023} \\
\hline employment $(\mathrm{N}=94)$ & $48.6 \%$ & $83.3 \%$ & $60.0 \%$ & $58.8 \%$ & $72.7 \%$ & $61.9 \%$ & & & \\
\hline other $(\mathrm{N}=37)$ & $34.3 \%$ & $16.7 \%$ & $20.0 \%$ & $23.5 \%$ & $22.7 \%$ & $23.8 \%$ & & & \\
\hline
\end{tabular}

Source: author's calculations.

The age structure of respondents was varied. The age group of 30-49 predominated in all clusters, except in Cluster 3, where the proportions of the 18-29 and 30-49 age groups were equal, and in Cluster 4 , where the $30-49$ age group and the over- 65 age group had a similar representation. This demonstrates that the negative attitudes towards both the NP and tourism and the rare visits to nature can be characteristic of different age groups.

While all clusters were dominated by respondents with secondary education, Clusters 2 and 5 had relatively higher proportions of people with university diplomas, and Cluster 4 had the highest percentage of respondents with elementary education.

The employment structure of respondents also differed between the clusters. Clusters 2 and 5 had high proportions of employed respondents, while Clusters 1,3, and 4 had relatively high proportions of 
unemployed. The "other" category incorporates working pensioners, pensioners, people on maternity or parental leave and students. This category was the most frequent in Cluster 1.

People in Cluster 4 were special because of their significant negative attitude towards the NP and tourism development and the lack of a direct relationship with nature. Therefore, it is not surprising that they also had a less positive attitude towards the role of scientific research in the NP. These negative attitudes are mostly typical for the less educated people of different age classes and with a relatively high proportion of unemployment. This definite negative attitude was shared by $11 \%$ of respondents.

In contrast, the least numerous Cluster 2 with $8 \%$ of the respondents included people with a positive attitude towards the NP. They were directly involved in tourism, and although they perceived the number of tourists differently, they considered tourism as the most important NP task. Their varied, but certainly not the worst, business and economic situation could be improved with increasing tourism. Respondents of this group also believed that the educational task of the NP is also important, as they scored the highest points on this task. They were mostly involved in the restaurant and accommodation business, and their facilities were frequently utilised by "schools in nature" kindergarten and school groups from Slovakia and Hungary. Therefore, it is unsurprising that they considered education as an important NP role. This group mainly incorporated productive-age, employed people with higher qualifications. At this point, we stated that our initial hypothesis $\mathrm{H} 2$ is fulfilled, i.e., the more positive attitudes towards the NP are shared by more educated, young middle-aged people, supporting the development of the tourism industry. Not surprisingly, these people do not plan to move away from the Slovak Karst area.

Cluster 3 includes $13 \%$ of respondents. These people shared positive attitudes towards the NP and tourism, but they perceived their economic situation as less favourable. This is also reflected in their ambiguous responses about emigration. More than half of them would move away if they could, but they appreciate karst values and consider tourism, education and research as the most important tasks of the NP. These attitudes were shared mostly by younger people with secondary or higher education and with a diverse employment situation.

Cluster 1 included $23 \%$ of the respondents. People belonging to this group had higher education, a diverse age structure and a mixed employment situation. Although most of them had rather unsatisfactory economic conditions, they maintained a positive perception of the NP and tourism. A large proportion of them, especially those who live in Krasnohorské Podhradie, Krasnohorská Dlhá Lúka and Plešivec villages, perceived high tourist visit frequency. Here we note that tourism and consequently the locals' perception about it abruptly diminished in the first two villages after Krásna Hôrka castle burned down in 2012. The castle has been under reconstruction since that time. Plešivec is another type of village, as it is an important regional traffic junction, with a southerly road towards Hungary and Domica Cave; thus, respondents saw loads of tourists, but they just passed through their village.

Cluster 5 is the largest group with $30 \%$ of the respondents. Although they had a generally positive economic situation, their views and attitudes towards the NP were diverse and ambiguous. Their low intention to emigrate from the Slovak Karst was unambiguously in connection with their good economic conditions. This cluster included mostly middle-aged and employed people, who had secondary or higher education.

Finally, Cluster 6 incorporated 14\% of the respondents, who had a satisfactory economic situation, but who rarely visit nature. They predominantly have secondary and higher qualification and a diverse age structure. Their economic situation is reflected in their unequivocal rejection of emigration. Respondents in this group significantly differed from those in other clusters by scoring lower points on the importance of certain NP tasks, such as the preservation of geological or biological values.

\section{Discussion}

Before discussing the results, we note that the percent values related to clusters found in our study should be considered only as rough estimates as the sample size is small. Therefore, our findings 
are exploratory rather than definite conclusions, and further research is necessary to increase the sample size and verify the statistical correctness of the identified factors and clusters about the views and attitudes of the local population towards the NP. However, we mention that a similarly small sample size was used in several other studies examining tourist typologies. Ryan and Montgomery (1994) [85] analysed the attitudes of Bakewell residents towards tourism (near Peak District NP, U.K.) using a sample of 160 people. Keng and Cheng (1999) [86] studied the tourist roles of Singapore vacationers based on a sample of 150. Cihar and Stankova (2006) [87] examined the attitudes of local people towards Podyji/Thaya River Basin NP (Czech Republic) using a total of 115 questionnaires filled in by residents. Winter and Gallon (2008) [88] explored the attitudes towards a tourism campaign in Australia based on 150 completed questionnaires. Grinberger et al. (2014) [89] used data from 68 visitors to characterize the time-space consumption of tourists. He and the previous authors agreed that although this sample size is small, it is sufficient for an exploratory study. Therefore, we also think that our sample size can help to roughly explore the significant types of local people's views and attitudes towards the Slovak Karst NP.

Table 7 shows clearly and concisely the complex description of the attitude clusters in the NP local population. We believe that these results can provide significant information to the development of the NP and tourism; thus, it can be communicated to the NP and regional planning managers.

In the following, we compare our results to those obtained in other national park surveys. According to Arnberger and Schoissengeier (2012) [13], residents often regard protected areas in their neighbourhood critically because of certain restrictions. Restrictions can be important in agriculture or forestry, so where private agricultural lands or forests add up to a significant part of the NP area, the local people experience a loss of their income because of the NP [90]. This opinion exists in the Slovak Karst NP as well, though not so intensively for two reasons: first, because agriculture is subordinate in this area as it is a karst terrain and second, because, during the communist era, people got used to the fact that the lands (and forests) belonged to the state, so they did not manage the land as private proprietors. The same is true for the nearby Aggtelek NP at the other side of the Slovakia-Hungary border, though agriculture was slightly more intensive there in historical times [7].

It is an important question of whether the NP can generate new revenues [90]. In addition to providing work to employees, the NP can generate income mostly through tourism. While in Aggtelek NP, the NP is the largest employer in the small region [9], this is not true for the Slovak Karst NP as the NP administration has one a few employees. On the other hand, tourism is more important there. However, it should be noted that the tourism of the Slovak Karst area is not directly related to the NP, and the NP as a tourism benchmark is not so deeply rooted in the thinking of local people [25]. Thus, the increased use of the NP as a marketing label can be suggested. Anyway, if tourism is improved and incomes begin growing, the profit should be fairly distributed among the NP (which needs it for its operation as state budgets are limited) and the local stakeholders. Our results support that people working in tourism have more positive views about the NP.

Moreover, we agree with Akyol et al. (2018) [90] that to increase local participation and commitment towards sustainable management and protection measures of the national park, the sense of belonging to the NP should be also strengthened. According to our survey, the majority of local people perceive the positive values of the NP (89\%) and consider it a "blessing" to live here (82\%) regardless of their economic situation or the restrictions due to environmental management. However, they often have only an indirect relationship with the NP. 
Table 7. Cluster characteristics including attitude toward emigration, perception of tourist numbers, opinions about NP tasks and socio-demographic parameters.

\begin{tabular}{|c|c|c|c|c|c|c|}
\hline Items & $\begin{array}{c}\text { Cluster } 1 \\
\text { (Positive Attitude } \\
\text { toward NP and Tourism; } \\
\text { Unsatisfactory } \\
\text { Economic Conditions) } \\
\mathrm{N}=35\end{array}$ & $\begin{array}{c}\text { Cluster } 2 \\
\text { (Very Positive Attitude } \\
\text { toward Tourism, Karst, } \\
\text { and Nature Protection) } \\
\mathrm{N}=12\end{array}$ & $\begin{array}{c}\text { Cluster } 3 \\
\text { (Unsatisfactory Economic } \\
\text { Conditions, but Significant } \\
\text { Relationship with Nature) } \\
\mathbf{N}=\mathbf{2 0}\end{array}$ & $\begin{array}{c}\text { Cluster } 4 \\
\text { (Negative Attitude } \\
\text { toward NP and Tourism } \\
\text { and Insignificant } \\
\text { Relationship with } \\
\text { Nature) } \\
\text { N }=17\end{array}$ & $\begin{array}{c}\text { Cluster } 5 \\
\text { (Good Economic } \\
\text { Conditions) } \\
\mathrm{N}=44\end{array}$ & $\begin{array}{c}\text { Cluster } 6 \\
\text { (Insignificant } \\
\text { Relationship with } \\
\text { Nature, but Good } \\
\text { Economic Conditions) } \\
\mathbf{N}=21\end{array}$ \\
\hline \multicolumn{7}{|c|}{ Attitude towards migration away from the NP and perception of local tourism } \\
\hline $\begin{array}{c}\text { If it were possible, would you } \\
\text { move away from the Slovak } \\
\text { Karst National Park? }\end{array}$ & no & no & yes & no & definite no & no \\
\hline $\begin{array}{c}\text { How often do tourists come to } \\
\text { vour village? }\end{array}$ & few tourists & mixed answers & few tourists & mixed answers & a lot of tourists & a lot of tourists \\
\hline \multicolumn{7}{|c|}{ The opinion of local people about the tasks of the NP } \\
\hline $\begin{array}{l}\text { Preservation of the biological } \\
\text { values }\end{array}$ & the most important & important & important & important & important & more or less important \\
\hline $\begin{array}{c}\text { Preservation of the geological } \\
\text { values (caves) }\end{array}$ & the most important & important & important & important & important & more or less important \\
\hline $\begin{array}{l}\text { Preservation of the cultural } \\
\text { values (e.g., monuments) }\end{array}$ & important & important & important & important & important & important \\
\hline $\begin{array}{l}\text { Preservation of the landscape } \\
\text { scientific research } \\
\text { education } \\
\text { tourism }\end{array}$ & $\begin{array}{l}\text { important } \\
\text { more or less important } \\
\text { important } \\
\text { important }\end{array}$ & $\begin{array}{l}\text { important } \\
\text { more or less important } \\
\text { important } \\
\text { important }\end{array}$ & $\begin{array}{c}\text { important } \\
\text { more or less important } \\
\text { important } \\
\text { important } \\
\text { Demographic characteristics }\end{array}$ & $\begin{array}{l}\text { important } \\
\text { less important } \\
\text { important } \\
\text { less important }\end{array}$ & $\begin{array}{l}\text { important } \\
\text { more or less important } \\
\text { important } \\
\text { important }\end{array}$ & $\begin{array}{c}\text { important } \\
\text { more or less important } \\
\text { important } \\
\text { important }\end{array}$ \\
\hline sex & mixed & mixed & mixed & mixed & mixed & mixed \\
\hline age & mixed & productive age & young productive age & mixed & mixed & mixed \\
\hline education & educated & the most educated & educated & less educated & mixed & educated \\
\hline Occupation & mixed & employed & $\begin{array}{l}\text { mixed and the most } \\
\text { unemployed }\end{array}$ & mixed & employment & mixed \\
\hline
\end{tabular}


In another karstic national park, the Triglav NP in Slovenia, a similar survey demonstrated that people who live inside the NP are less satisfied with their quality of life than those who live outside the park (37\% versus $51.3 \%$, [91]). However, as the previous authors pointed out, these differences can be explained by the fact that the people living outside the park live generally in larger settlements. In the case of Slovak Karst NP or Aggtelek NP or many other karstic NPs, smaller rural settlements are indeed predominant; thus, the opinion of local residents often reflects their situation of living in a village and not the direct impact of living in an NP. As a result, in similar surveys, local residents usually mention better employment possibilities, better rural development policy, better services (schools, health) and better road connections (or public transport) as their most important wishes [9,91]. People living in NPs situated along country borders often have a feeling of remoteness, even if the area is not so far from larger cities [9]; this feeling is often mentioned by the residents of the Slovak Karst NP as well [75].

Futhermore, the insufficiently developed infrastructure may represent a negative factor for the development of tourism. Therefore, tourism-related investments may contribute to the development of local infrastructure, thus becoming an instrument for regional development, as was demonstrated by research in the NPs of Finland or Poland [63,69,92]. Support for tourism infrastructure development and nature-based tourism can lead to the reversal of migration trends and thus halt the depopulation in the NPs [62]. In our survey, only $8 \%$ of respondents confirmed a positive attitude and interest in the tourism industry. This did not fulfil our initial assumption H1. However, according to Puhakka (2008) [68], strengthening the role of different types of tourism like nature tourism [93], ecotourism [94] or geotourism $[95,96]$ would support the integration of the social and conservation goals-if the sustainability principles are taken into consideration. NPs and protected areas exist within a dynamic social and political setting that is sometimes difficult to understand and challenging to predict [97].

As noted by Telbisz et al. (2014) [6], karst NPs are often located in relatively poor regions. Therefore, the attitudes of local people often correlate with the underdeveloped economic situation of the region. Vorkinn and Riese (2001) [98] noted that stronger socio-economic and cultural attachment to a place results in a higher degree of sensitivity to site management. Therefore, the attitudes of local people towards the economic situation are also important. At the same time, Trakolis (2001) [58] added that "protected areas cannot co-exist with communities that are hostile to them, but they can achieve significant social and economic objectives when placed in a proper context". In our case study, while $52 \%$ of locals (Clusters 5 and 6) stated satisfaction with the economic situation, up to $37 \%$ (Clusters 1 and 3) were significantly dissatisfied. However, more than $44 \%$ of the population said that their economic situation in the NP had improved over the past 10 years. Anyway, this improvement is probably not directly linked to the operation of the NP. A similar result was presented in the study of Trakolis (2001) [58] from the area of the Vikos-Aoos NP in Greece, where the economic situation of 29\% of local people has improved in the 25 years of the NP's existence. This proportion included mainly the population working in the tourism sector, while in our area, the mentioned improvement included people with various economic activities or professions.

Higher levels of awareness and more positive attitudes towards NPs are generally accompanied by higher education levels, older age and the commitment to continue living in the area. Cluster 3 $(13 \%)$ is an interesting group, as it includes people with a bad economic situation and rather negative opinions about the NP and tourism. However, they have a direct relationship with the surrounding nature. As Schindler et al. (2011) [64] noted, a positive attitude towards nature can be a good starting point to enhance people's involvement in nature conservation measures and sustainable development. In our study, it was found that people living in unsatisfactory economic conditions and lacking any relation to the NP or nature had the most negative attitudes towards conservation. This might suggest that as benefits from an NP increase, people not receiving a share of the benefits may become more disappointed and display more negative attitudes [99]. As we observed, many local people shared certain negative attitudes towards the NP and its management. Seventy-three percent of the respondents think that they do not have any influence on the management of the NP, and forty-nine percent of them see no (personal, economic or other) positive effect on their life related to the NP. Eagles 
(2007) [100] already pointed out that there is a need for sufficient communication between local people, stakeholders and park and protected area managers. Open communication is seen as one opportunity to foster trust between multiple actors and generate more flexible modes of governance $[28,101]$.

\section{Conclusions}

Despite close relationships between the Slovak Karst NP and the surrounding communities, the high degree of NP protection often leads to conflicts between the NP administration and local communities. Therefore, a common consensus is currently searched for to maintain sustainable development in the area of this NP. According to the views of the older generations, the NP primarily serves the purpose of nature protection. Today, the harmonization of the interests of stakeholders and organizations is generally a high priority for park managers [22,102]. Our survey demonstrated that for the local population, the Slovak Karst NP is more a resource than a constraint, which is also the answer to the third research question. However, we must add that many local people perceive this resource simply as a "quality environment".

This exploratory study investigated differences in the views and attitudes of local people clusters towards current NP tasks and priorities. Factor analysis of 149 filled questionnaires produced four attitude factors: "General opinion on NP and tourism development", "Direct relationship with nature", "Economic conditions" and "Involvement in tourism and attitude to karst and nature protection". Cluster analysis based on the four factors provided six local people clusters, and one-way ANOVA tests revealed significant differences (at $p<0.001$ ) in local attitude factors in these six clusters. Our results highlighted that $45 \%$ of the sampled population (of Clusters 1, 2 and 3) generally had positive attitudes towards the NP and nature. Furthermore, twenty-nine-point-five percent of respondents (in Cluster 5) had neutral views about the NP, whereas the remaining 25.5\% of local people (in Clusters 4 and 6) maintained negative attitudes. Based on these data, we can say that the first part of our first hypothesis (i.e., the majority of local people have positive attitudes towards the NP) was not fulfilled, because the negative and neutral opinions slightly dominate over the positive ones. On the other hand, our second hypothesis (i.e., more positive attitudes are connected with higher education, younger age, closer relationship with tourism and stronger attachment to place) proved to be true.

Although local people mostly have a positive perception of tourism in the park, it cannot be judged whether the park sustainably facilitates tourism development or not. The key problems identified are the insufficient regional development of the area in and around the Slovak Karst NP and the low level of involvement of local people in the development of tourism [103]. The Slovak Karst NP is situated in an under-developed and poor area of Slovakia, and local attitudes are often dependent on both the individual and the overall economic situation of the settlement. Among the respondents, forty-three-point-six percent perceived the economic situation positively (Clusters 5 and 6), 19.5\% were neutral (Clusters 2 and 4), and up to 36.9\% evaluated it negatively (Clusters 1 and 3). However, we found that the negative economic assessment did not significantly affect respondents' attitudes towards the NP, tourism and visiting natural sites. The third hypothesis that tourism is considered by most people as the main potential driver for sustainable development has not been confirmed. This attitude is shared by local people who are directly involved in the tourism industry. Only a relatively small $8 \%$ of local people are directly involved in NP-related tourism, but there is another group of local people with satisfactory economic conditions, who do not show significant interest in karst or NP values.

At this point, we remind the reader that the current study is an exploratory attempt to profile local people's views and attitudes, but it cannot claim to be wholly conclusive in the statistical meaning due to the small sample size. A larger sample would more accurately represent the typology of local people; therefore, this research can be considered as a pilot study, which should be extended in the future to verify the validity of the identified attitude factors and local people clusters. Future research is also planned to explore the views and attitudes of tourists towards the NP. 
In the following, we draw some conclusions, which go beyond the simple statistical interpretation of the results, and try to outline how the management of the NP could be modified taking into consideration our results. The results of the current research showed a positive attitude towards the NP or tourism in almost half of the examined sample. The priority of NP management should therefore be to improve effective communication with local groups. The Slovak Karst NP should find ways to positively influence the socio-economic situation of the area, where unemployment and outward migration are the main problems. At present, the administration of the NP has only 11 employees. This number could be increased, and local people should be either directly employed or indirectly employed for external tasks through contracts. Thus, it is recommended for the Slovak Karst NP, which is an organization with relatively significant human and financial resources (in the local context), to provide certain operational sectors within the micro-region, including accommodation and other tourist institutions. Therefore, one of the main recommendations for the Slovak Karst NP is to add local sustainable development to the objectives of the NP in the official documents. Another suggestion is that the benefits from the sustainable utilization of nature should also be shared with the local population. At the same time, the above facts provide an answer to the first research question. Here, we found that until now, the Slovak Karst NP had only a limited role in the socio-economic development of the region. However, with the above recommendations, the NP can undertake a more active role in local socio-economic development according to the new paradigm of Mose (2007) [11] and Mika and Zawilinska (2015) [104]. Greater support for tourism development would significantly improve the Slovak Karst socio-economic situation and enable local entrepreneurs to become increasingly involved in tourism and regional development. Our research reveals that investment in nature-based tourism would greatly contribute to developing regional accommodation, catering and other services, and this could be an appropriate starting point for the NP management to strengthen the NP and local community interaction.

The Slovak Karst NP management is a key organisation, and it should focus on improving resource efficiency utilising the participatory approach presented by Macura et al. (2010) [22]. This would strengthen and build the local community, develop the ability to cooperate with stakeholders and manage partnerships, which promote natural and cultural wealth. The emphasis on social development would improve local quality of life and halt emigration from the region.

Generalizing our conclusions, we can state that park-people relationships can be improved at several levels. First, the involvement of the NP in local education in schools and training for adults about the uniqueness of karst processes and landforms would help people to think in a (more) sustainable way. Furthermore, knowledge can also stimulate them to be more active in the tourism industry (e.g., working as guides). Second, councils including NP and local people representatives are crucial in discussing problems and initiatives. These forums would help the NP to communicate and explain the sustainability measurements to the local people not only in general, but in a local context as well. Third, the NP can "attract" large projects, in which local people can work as entrepreneurs, and this may contribute to increasing the entrepreneurial activity in otherwise less developed karst regions.

Author Contributions: Conceptualization, J.N.D., A.G., and T.T.; methodology, J.N.D. and T.T.; investigation, L.B., J.N.D., and A.G.; resources, J.N.D., A.G., and T.T.; data curation, J.N.D. and L.B.; writing, original draft preparation, J.N.D.; writing, review and editing, J.N.D., A.G., and T.T.; project administration, T.T.; funding acquisition, T.T., A.G., and J.N.D. All authors have read and agreed to the published version of the manuscript.

Funding: This research was funded by the National Research, Development, and Innovation Office Hungary (NKFIH) K124497 project.

Acknowledgments: The authors would like to thank the reviewers for their comments, suggestions and notes, which significantly helped to improve the original version of the paper.

Conflicts of Interest: The authors declare no conflict of interest. 


\section{References}

1. Zube, E.H.; Busch, M.L. Park-people relationships: An international review. Landsc. Urban Plan. 1990, 19,117-131. [CrossRef]

2. Ruban, D.A. Karst as important resource for geopark-based tourism: Current state and biases. Resources 2018, 7, 82. [CrossRef]

3. Dollma, M. Canyons of Albania and geotourism development. Acta Geoturistica 2018, 9, 28-34. [CrossRef]

4. Tomić, N.; Antić, A.; Marković, S.B.; Đorđević, T.; Zorn, M.; Valjavec, M.B. Exploring the potential for speleotourism development in eastern serbia. Geoheritage 2019, 11, 359-369. [CrossRef]

5. Telbisz, T.; Mari, L. The significance of karst areas in European national parks and geoparks. Open Geosci. 2020, 12, 117-132. [CrossRef]

6. Telbisz, T.; Bottlik, Z.; Mari, L.; Kőszegi, M. The impact of topography on social factors, a case study of Montenegro. J. Mt. Sci. 2014, 11, 131-141. [CrossRef]

7. Telbisz, T.; Bottlik, Z.; Mari, L.; Petrvalská, A. Exploring relationships between karst terrains and social features by the example of gömör-torna karst (hungary-slovakia). Acta Carsologica 2015, 44, 121-137. [CrossRef]

8. Telbisz, T.; Imecs, Z.; Mari, L.; Bottlik, Z. Changing human-environment interactions in medium mountains: The Apuseni Mts (Romania) as a case study. J. Mt. Sci. 2016, 13, 1675-1687. [CrossRef]

9. Telbisz, T.; Gruber, P.; Mari, L.; Kőszegi, M.; Bottlik, Z.; Standovár, T. Geological heritage, geotourism and local development in aggtelek national park (ne hungary). Geoheritage 2020, 12, 5. [CrossRef]

10. Butler, R.; Boyd, S. Tourism and national parks-a long but uneasy relationship. In Tourism and National Parks: Issues and Implications; John Wiley \& Sons, Inc.: Hoboken, NJ, USA, 2000; pp. 3-11. ISBN 0471988944.

11. Mose, I. Protected Areas and Regional Development in Europe: Towards a New Model for the 21st Century; Ashgate: Aldershot, UK, 2007; ISBN 9780754648017.

12. Frost, W.; Hall, C.M. Tourism and National Parks: International Perspectives on Development, Histories, and Change; Routledge: London, UK; New York, NY, USA, 2009; ISBN 9780415471565.

13. Arnberger, A.; Schoissengeier, R. The other side of the border: Austrian local residents' attitudes towards the neighbouring Czech Šumava National Park. J. Nat. Conserv. 2012, 20, 135-143. [CrossRef]

14. Baral, N.; Heinen, J.T. Resources use, conservation attitudes, management intervention and park-people relations in the Western Terai landscape of Nepal. Environ. Conserv. 2007, 34, 64-72. [CrossRef]

15. Silori, C.S. Perception of local people towards conservation of forest resources in Nanda Devi biosphere reserve, north-western Himalaya, India. Biodivers. Conserv. 2007, 16, 211-222. [CrossRef]

16. Vodouhê, F.G.; Coulibaly, O.; Adégbidi, A.; Sinsin, B. Community perception of biodiversity conservation within protected areas in Benin. For. Policy Econ. 2010, 12, 505-512. [CrossRef]

17. Mika, M.; Zawilińska, B.; Kubal-Czerwińska, M. Exploring the determinants of local people's attitude towards national parks in Poland. Folia Geogr. 2019, 61, 5-16.

18. Hayes, T.M. Parks, people, and forest protection: An institutional assessment of the effectiveness of protected areas. World Dev. 2006, 34, 2064-2075. [CrossRef]

19. Stoll-Kleemann, S. Evaluation of management effectiveness in protected areas: Methodologies and results. Basic Appl. Ecol. 2010, 11, 377-382. [CrossRef]

20. Walpole, M.J.; Goodwin, H.J. Local attitudes towards conservation and tourism around Komodo National Park, Indonesia. Environ. Conserv. 2001, 28, 160-166. [CrossRef]

21. Tomaškinová, J.; Tomaškin, J. Integrovaný Manažment Národného Parku Slovenský Kras; Belianum, Matej Bel University Publishing, Faculty of Natural Sciences: Banská Bystrica, Slovakia, 2013; ISBN 9788055705897.

22. Macura, B.; Bojovic, D.; Petric, I.; Cosic, N.; Tadic, M.; Jarić, I.; Knezevic, J.; Špirić, J.; Jaric, M. Local Communities and Management of Protected Areas in Serbia; Ecological Society Endemit: Belgrade, Serbia, 2010.

23. Getzner, M. Impacts of protected areas on regional sustainable development: The case of the Hohe Tauern national park (Austria). Int. J. Sustain. Econ. 2010, 2, 419-441. [CrossRef]

24. Mayer, M.; Müller, M.; Woltering, M.; Arnegger, J.; Job, H. The economic impact of tourism in six German national parks. Landsc. Urban Plan. 2010, 97, 73-82. [CrossRef] 
25. Nolte, B. Sustainable tourism in biosphere reserve of east central European countries: Case studies from Slovakia, hungary and the czech republic. In Policies, Methods and Tools for Visitor Management, Proceedings of the Second International Conference on Monitoring and Management of Visitor Flows in Recreational and Protected Areas, Rovaniemi, Finland, 16-20 June 2004; METLA: Vanta, Finland, 2004; pp. 349-356.

26. Krajčovičová, D. Najefektívnejšia ochrana krajiny je jej ciel'avedomé využívanie. Acta Environ. Univ. Comen. 2006, 14, 53-63.

27. Kapoor, I. Towards participatory environmental management? J. Environ. Manag. 2001, 63, $269-279$. [CrossRef] [PubMed]

28. Puhakka, R.; Sarkki, S.; Cottrell, S.P.; Siikamäki, P. Local discourses and international initiatives: Sociocultural sustainability of tourism in Oulanka National Park, Finland. J. Sustain. Tour. 2009, 17, 529-549. [CrossRef]

29. Mika, M.; Zawilińska, B. Babia Góra national park as a business partner in the local economy: Exploring cooperation factors and barriers. Folia Geogr. 2016, 58, 22-34.

30. Mika, M.; Zawilinska, B.; Pawlusinski, R. Exploring the economic impact of national parks on the local economy. Functional approach in the context of Poland's transition economy. Hum. Geogr. 2016, 10, 5-21. [CrossRef]

31. Dudley, N. Guidelines for Applying Protected Area Management Categories; IUCN: Gland, Switzerland, 2008; ISBN 978-2-8317-1086-0.

32. Phillips, A. Turning ideas on their head: The new paradigm for protected areas. George Wright Forum 2003, 20, 8-32.

33. Borrini, G.; Dudley, N.; Jaeger, T.; Lassen, B.; Pathak, N.; Phillips, A.; Sandwith, T. Governance of Protected Areas: From Understanding to Action; The World Conservation Union (IUCN): Gland, Switzerland, 2013.

34. Mika, M.; Pawlusiński, R.; Zawilińska, B. Park Narodowy a Gospodarka Lokalna Model Relacji Ekonomicznych na Przykładzie Babiogórskiego Parku Narodowego; IGIGP, Uniwersytet Jagielloński: Kraków, Poland, 2016.

35. McNeely, J.A. Parks for Life: Report of the Fourth World Congress on National Parks and Protected Areas, 10-21 February 1992; IUCN: Gland, Switzerland, 1993; ISBN 978-2-8317-0162-2.

36. Ghimire, K.B.; Pimbert, M.P. Social Change and Conservation: Environmental Politics and Impacts of National Parks and Protected Areas; Earthscan Publications: London, UK, 1997; ISBN 978-1-85383-410-3.

37. Sabolová, E. Vybrané vplyvy cestovného ruchu na región a teoretické východiská percepcie cestovného ruchu. Folia Geogr. 2013, 55, 119-128.

38. Muganda, M.; Sirima, A.; Ezra, P.M. The role of local communities in tourism development: Grassroots perspectives from Tanzania. J. Hum. Ecol. 2013, 41, 53-66. [CrossRef]

39. Godfrey, K.; Clarke, J. The Tourism Development Handbook: A Practical Approach to Planning and Marketing; Cassell: London, UK, 2000; ISBN 978-0-8264-5337-2.

40. Hall, D.; Richards, G. Tourism and Sustainable Community Development; Routledge: London, UK; New York, NY, USA, 2002; ISBN 978-1-134-59105-3.

41. Bushell, R.; McCool, S.F. Tourism as a tool for conservation and support of protected areas: Setting the agenda. In Tourism and Protected Areas: Benefits Beyond Boundaries; CAB International: Wallingford, UK, 2006; pp. 12-26.

42. Tosun, C. Expected nature of community participation in tourism development. Tour. Manag. 2006, 27, 493-504. [CrossRef]

43. Jamal, T.; Stronza, A. Collaboration theory and tourism practice in protected areas: Stakeholders, structuring and sustainability. J. Sustain. Tour. 2009, 17, 169-189. [CrossRef]

44. Aref, F.; Gill, S.S.; Aref, F. Tourism development in local communities: As a community development approach. J. Am. Sci. 2010, 6, 157-161. [CrossRef]

45. Kim, S.S.; Kim, M.; Park, J.; Guo, Y. Cave tourism: Tourists' characteristics, motivations to visit, and the segmentation of their behavior. Asia Pac. J. Tour. Res. 2008, 13, 299-318. [CrossRef]

46. Rosič, M.; Fogaš, A.; Barabas, D. Porovnanie návštevnosti sprístupnených jaskýň Národného parku slovenský kras a národného parku aggteleki. In Zborník Referátov zo 4. Medzinárodnej Konferencie o Biosférických Rezerváciách SR; Technická Univerzita: Zvolen, Slovakia, 2002; pp. 189-193.

47. Hochmuth, Z. Krasový fenomén a jeho vplyv na formovanie infraštruktúry turistického ruchu. Urbánne Kraj. Štúdie 1997, 2, 116-130.

48. Fennell, D.; Weaver, D. The ecotourium concept and tourism-conservation symbiosis. J. Sustain. Tour. 2005, 13, 373-390. [CrossRef] 
49. Zachrisson, A.; Sandell, K.; Fredman, P.; Eckerberg, K. Tourism and protected areas: Motives, actors and processes. Int. J. Biodivers. Sci. Manag. 2006, 2, 350-358. [CrossRef]

50. Hammer, T.; Mose, I.; Siegrist, D.; Weixlbaumer, N. Protected areas and regional development in Europe: Towards a new model for the 21st century. In Protected Areas and Regional Development in Europe. Towards a New Model for the 21st Century; Ashgate: Aldershot, UK, 2007; pp. 233-246.

51. Eagles, P.F.J.; Haynes, C.D.; McCool, S.F. Sustainable Tourism in Protected Areas: Guidelines for Planning and Management; IUCN: Gland, Switzerland; Cambridge, UK, 2002; ISBN 978-2-8317-0648-1.

52. McCool, S.F.; Patterson, M.E. Trends in Recreation, Tourism and Protected Area Planning; CAB International: Wallingford, CT, USA, 2000.

53. Fiallo, E.A.; Jacobson, S.K. Local communities and protected areas: Attitudes of rural residents towards conservation and machalilla national park, Ecuador. Environ. Conserv. 1995, 22, 241-249. [CrossRef]

54. Ite, U.E. Community perceptions of the cross river national park, Nigeria. Environ. Conserv. 1996, 23, 351-357. [CrossRef]

55. De Boer, W.F.; Baquete, D.S. Natural resource use, crop damage and attitudes of rural people in the vicinity of the maputo elephant reserve, Mozambique. Environ. Conserv. 1998, 25, 208-218. [CrossRef]

56. Mehta, J.N.; Kellert, S.R. Local attitudes toward community-based conservation policy and programmes in Nepal: A case study in the Makalu-Barun Conservation Area. Environ. Conserv. 1998, 25, 320-333. [CrossRef]

57. Čihař, M.; Tancošová, L.; Třebický, V. Národny park Šumava a vybrané aspekty jeho udržitelného rozvoje - hodnocení místnimi obyvateli/obce Borová Lada, Horská Kvilda, Kvilda, Modrava, Flipova Hut', Srní a Prášili). Silva Gabreta 2000, 5, 195-216.

58. Trakolis, D. Local people's perceptions of planning and management issues in Prespes Lakes National Park, Greece. J. Environ. Manag. 2001, 61, 227-241. [CrossRef]

59. Hiedanpää, J. European-wide conservation versus local well-being: The reception of the Natura 2000 reserve network in Karvia, SW-Finland. Landsc. Urban Plan. 2002, 61, 113-123. [CrossRef]

60. Wallner, A.; Bauer, N.; Hunziker, M. Perceptions and evaluations of biosphere reserves by local residents in Switzerland and Ukraine. Landsc. Urban Plan. 2007, 83, 104-114. [CrossRef]

61. Dimitrakopoulos, P.G.; Jones, N.; Iosifides, T.; Florokapi, I.; Lasda, O.; Paliouras, F.; Evangelinos, K.I. Local attitudes on protected areas: Evidence from three Natura 2000 wetland sites in Greece. J. Environ. Manag. 2010, 91, 1847-1854. [CrossRef] [PubMed]

62. Petrova, S.; Čihař, M.; Bouzarovski, S. Local nuances in the perception of nature protection and place attachment: A tale of two parks. Area 2011, 43, 327-335. [CrossRef]

63. Pietrzyk-Kaszyńska, A.; Cent, J.; Grodzińska-Jurczak, M.; Szymańska, M. Factors influencing perception of protected areas-The case of Natura 2000 in Polish Carpathian communities. J. Nat. Conserv. 2012, 20, 284-292. [CrossRef]

64. Schindler, S.; Cimadom, A.; Wrbka, T. The attitude towards nature and nature conservation on the urban fringes. Innov. Eur. J. Soc. Sci. Res. 2011, 24, 379-390. [CrossRef]

65. Bell, J.; Stockdale, A. Evolving national park models: The emergence of an economic imperative and its effect on the contested nature of the 'national' park concept in Northern Ireland. Land Use Policy 2015, 49, 213-226. [CrossRef]

66. Arpin, I.; Cosson, A. The category of mountain as source of legitimacy for national parks. Environ. Sci. Policy 2015, 49, 57-65. [CrossRef]

67. Xu, F.; Fox, D. Modelling attitudes to nature, tourism and sustainable development in national parks: A survey of visitors in China and the UK. Tour. Manag. 2014, 45, 142-158. [CrossRef]

68. Puhakka, R. Increasing role of tourism in Finnish national parks. Fennia-Int. J. Geogr. 2008, 186, 47-58.

69. Saarinen, J. Protected areas and regional development issues in northern peripheries: Nature protection, traditional economies and tourism in the Urho Kekkonen national park, Finland. In Protected Areas and Regional Development in Europe. Towards a New Model for the 21st Century; Ashgate: Aldershot, UK, 2007; pp. 199-211.

70. Cellarius, B.A. In the Land of Orpheus: Rural Livelihoods and Nature Conservation in Postsocialist Bulgaria; Univ of Wisconsin Press: Madison, WI, USA, 2004; ISBN 978-0-299-20150-0.

71. Staddon, C. Towards a critical political ecology of human-forest interactions: Collecting herbs and mushrooms in a Bulgarian locality. Trans. Inst. Br. Geogr. 2009, 34, 161-176. [CrossRef] 
72. Kőszegi, M.; Bottlik, Z.; Telbisz, T.; Gruber, P. The almighty state for the protection of nature: The Hungarian case study of post-socialist national parks. In Proceedings of the AAG, American Association of Geographers 2019 Annual Meeting, Washington, DC, USA, 6 April 2019.

73. Oleśniewicz, P.; Pytel, S.; Markiewicz-Patkowska, J.; Szromek, A.R.; Jandová, S. A model of the sustainable management of the natural environment in national parks-A case study of national parks in Poland. Sustainability 2020, 12, 2704. [CrossRef]

74. Chape, S.; Spalding, M.; Jenkins, M. The World's Protected Areas: Status, Values and Prospects in the 21st Century; University of California Press: Berkeley, CA, USA, 2008.

75. Gessert, A.; Nestorová-Dická, J.; Sninčák, I. The dynamics of tourist excursion ratios in Slovakia show caves from 2000 to 2014. Geogr. Tidsskr. Dan. J. Geogr. 2018, 118, 173-183. [CrossRef]

76. Lee, T.H. Influence analysis of community resident support for sustainable tourism development. Tour. Manag. 2013, 34, 37-46. [CrossRef]

77. Yang, Y.; Xia, Y. On the number of factors to retain in exploratory factor analysis for ordered categorical data. Behav. Res. Methods 2015, 47, 756-772. [CrossRef]

78. Basto, M.; Pereira, J.M. An SPSS r-menu for ordinal factor analysis. J. Stat. Softw. 2012, 46, 1-29. [CrossRef]

79. Dolan, C.V. Factor analysis of variables with 2, 3, 5 and 7 response categories: A comparison of categorical variable estimators using simulated data. Br. J. Math. Stat. Psychol. 1994, 37, 309-326. [CrossRef]

80. Ferrando, P.J.; Lorenzo-Seva, U. Program FACTOR at 10: Origins, development and future directions. Psicothema 2017, 236-240. [CrossRef]

81. Aldenderfer, M.; Blashfield, R. Cluster Analysis; Sage: Severly Hills, CA, USA, 1984; ISBN 978-0-8039-2376-8.

82. Korec, P. Regionálny Rozvoj Slovenska v Rokoch 1989-2004: Identifikácia Menej Rozvinutỳch Regiónov Slovenska; Geo-Grafika: Bratislava, Slovakia, 2005.

83. Michálek, A.; Madajová, M.S. Identifying regional poverty types in Slovakia. GeoJournal 2019, 84, 85-99. [CrossRef]

84. Nestorová Dická, J.; Gessert, A.; Sninčák, I. Rural and non-rural municipalities in the Slovak Republic. J. Maps 2019, 15, 84-93. [CrossRef]

85. Ryan, C.; Montgomery, D. The attitudes of Bakewell residents to tourism and issues in community responsive tourism. Tour. Manag. 1994, 15, 358-369. [CrossRef]

86. Keng, K.A.; Cheng, J.L.L. Determining tourist role typologies: An exploratory study of singapore vacationers. J. Travel Res. 2016. [CrossRef]

87. Cihar, M.; Stankova, J. Attitudes of stakeholders towards the Podyji/Thaya River Basin National Park in the Czech Republic. J. Environ. Manag. 2006, 81, 273-285. [CrossRef]

88. Winter, C.; Gallon, S. Exploring attitudes towards tourism australia's 'where the bloody hell are you?' campaign. Curr. Issues Tour. 2008, 11, 301-314. [CrossRef]

89. Grinberger, A.Y.; Shoval, N.; McKercher, B. Typologies of tourists' time-space consumption: A new approach using GPS data and GIS tools. Tour. Geogr. 2014, 16, 105-123. [CrossRef]

90. Akyol, A.; Türkoğlu, T.; Bekiroğlu, S.; Tolunay, A. Resident perceptions of livelihood impacts arising from the kizildağ national park, Turkey. Environ. Dev. Sustain. 2018, 20, 1037-1052. [CrossRef]

91. Zurc, J.; Udovč, A. Local inhabitants' opinion about the triglav national park management. Sociol. Prost. 2009, 47, 43-56.

92. Saarinen, J. Tourism in the Northern Wildernesses: Wilderness discourses and the development of nature-based tourism in northern Finland. In Nature-Based Tourism in Peripheral Areas; Channel View Publications: Bristol, UK, 2004; pp. 36-49. ISBN 978-1-84541-002-5.

93. Wells, M.P. Economic Perspectives on Nature Tourism, Conservation and Development; Environment Department, World Bank: Washington, DC, USA, 1997.

94. Donohoe, H.M.; Needham, R.D. Ecotourism: The evolving contemporary definition. J. Ecotourism 2006, 5, 192-210. [CrossRef]

95. Hose, T.A. Towards a history of geotourism: Definitions, antecedents and the future. Geol. Soc. Lond. Spec. Publ. 2008, 300, 37-60. [CrossRef]

96. Štrba, L'.; Kolačkovská, J.; Kudelas, D.; Kršák, B.; Sidor, C. Geoheritage and geotourism contribution to tourism development in protected areas of slovakia—theoretical considerations. Sustainability 2020, 12, 2979. [CrossRef] 
97. Gartner, W.C.; Lime, D.W. Trends in Outdoor Recreation, Leisure, and Tourism; CAB International: Wallingford, UK, 2000; ISBN 978-0-85199-713-1.

98. Vorkinn, M.; Riese, H. Environmental Concern in a Local Context: The Significance of Place Attachment Marit Vorkinn, Hanne Riese. 2001. Available online: https://journals.sagepub.com/doi/abs/10.1177/ 00139160121972972 (accessed on 23 October 2020).

99. Doğan, H.Z. Forms of adjustment: Sociocultural impacts of tourism. Ann. Tour. Res. 1989, 16, $216-236$. [CrossRef]

100. Eagles, P.F.J. Global trends affecting tourism in protected areas. In Tourism and Protected Areas: Benefits Beyond Boundaries. The Vth IUCN World Parks Congress; Bushell, R., Eagles, P., Eds.; CABI: Wallingford, CT, USA, 2007; pp. 27-43. ISBN 978-0-85199-022-4.

101. Kyllönen, S.; Calpaert, A.; Heikkinen, H.; Jokinen, M.; Kumpula, J.; Marttunen, M.; Muje, K.; Raitio, K. Conflict management as a means to the sustainable use of natural resources. Silva Fenn. 2006, 40, 687-728. [CrossRef]

102. Ruschkowski, E. Causes and potential solutions for conflicts between protected area management and local people in Germany. In Rethinking Protected Areas in a Changing World, Proceedings of the 2009 George Wright Society Biennial Conference on Parks, Protected Areas, and Cultural Sites, 2-6 March 2009; The George Wright Society: Hancock, MI, USA; pp. 200-244.

103. Balmford, A.; Beresford, J.; Green, J.; Naidoo, R.; Walpole, M.; Manica, A. A Global Perspective on Trends in Nature-Based Tourism. PLoS Biol. 2009, 7, e1000144. [CrossRef] [PubMed]

104. Mika, M.; Zawilińska, B. National Parks' impact on the local development according to the new paradigm of protected areas' operation: Experience from Polish economy. In Third International Conference on Emerging Research Paradigms in Business and Social Science; Middlesex University: Dubai, UAE, 2015; pp. 418-434.

Publisher's Note: MDPI stays neutral with regard to jurisdictional claims in published maps and institutional affiliations. 